\title{
Productivity and photosynthetic pigments in bell pepper plants grown in soil with biofertilizer and protected against water loss
}

\author{
Antonio João de Lima Neto $1 *$ (1), Tony Andreson Guedes Dantas ${ }^{2}$, Lourival Ferreira Cavalcante ${ }^{3}$, \\ Adriana Araújo Diniz, Stênio Andrey Guedes Dantas ${ }^{5}$, Antônio Gustavo de Luna Souto ${ }^{6}$
}

10.1590/0034-737X202168010005

\begin{abstract}
The search for techniques that maximize the use of water is becoming necessary for the sustainability of agriculture in semi-arid areas. In this sense, the present work aimed to evaluate the effects of soil protection against water loss and the use of bovine biofertilizer on fruit production and chlorophyll content in bell pepper plants. The experiment was conducted in the municipal district of Nova Floresta in the semi-arid region of the State of Paraíba during the period of August 2010 to February 2011. The experimental design was a randomized block design with four repetitions in a $2 \times 2$ $\times 2$ factorial scheme, corresponding to soil without and with bovine biofertilizer, without and with mulch, and without and with side coating of the grooves with polyethylene film, to reduce water loss through evaporation and lateral movement of water. The results showed that the use of side coatings of the grooves led to greater production, generating productivity gains in bell pepper cultivation. The association between side coating of the grooves and mulching of the soil resulted in increased levels of chlorophyll, but the bovine biofertilizer $\times$ side coating $\times$ mulch interaction inhibited the production of chlorophyll in the plants.
\end{abstract}

Keywords: Capsicum annuит L.; chlorophyll; mulch; reduction of water loss.

\section{INTRODUCTION}

Bell pepper (Capsicum annuum L.) is among the ten most grown vegetables and is of great economic importance in Brazilian markets (Melo et al., 2017; Santos et al., 2020; Sediyama et al., 2014). Bell pepper cultivation requires a regular supply of water throughout the growing cycle, water deficiency being one of the most limiting factors to obtaining high yields (Cosic et al., 2015; Malika et al., 2019; Sezen et al., 2019).

In the semi-arid conditions of the northeastern region of Brazil, water is a resource that has become increasingly scarce. This problem, in addition to the global climate changes that are occurring, requires vegetable farmers to adopt techniques that increase the efficiency of irrigation and water use (Kuşçu et al., 2016).
Greater water-use efficiency (WUE) can be obtained with the use of crop management techniques that minimize the water loss by evapotranspiration and by lateral movement, which reduce the water content of the root environment of plants. In the case of vegetables, a practice widely used by producers is the use of ground cover, which, in addition to reducing evaporative water loss, exerts weed control (Braga et al., 2017; Liang et al., 2011; Rocha et al., 2018). Ground cover also improves the nutritional status of plants, which is reflected by the increased productivity, and thus is a practice recommended for use in semi-arid regions, where availability of water resources is limited (Braga et al., 2017; Rocha et al., 2018).

Management practices that contribute to greater retention of soil moisture near the root system of plants,

\footnotetext{
Submitted on September $9^{\text {th }}, 2019$ and accepted on September $28^{\text {th }}, 2020$.

${ }^{1}$ Universidade Federal do Ceará, Departamento de Fitotecnia, Fortaleza, Ceará, Brazil. limanetoagro@ hotmail.com

${ }^{2}$ Instituto Federal de Educação, Ciência e Tecnologia do Ceará, Tianguá, Ceará, Brazil. tony.dantas@ifce.edu.br

${ }^{3}$ Universidade Federal da Paraíba, Departamento de Solos e Engenharia Rural, Areia, Paraíba, Brazil. lofeca@cca.ufpb.br

${ }^{4}$ Universidade Estadual do Maranhão, Balsas, Maranhão, Brazil. adrisolos2016@ gmail.com

${ }_{5}^{5}$ Engenheiro Agrônomo do Canteiro Cheiro Verde, Nova Floresta, Paraíba, Brazil. stenioandrey @ gmail.com

${ }^{6}$ Universidade Federal da Paraíba, Departamento de Fitotecnia e Ciências Ambientais, Areia, Paraíba, Brazil. gusluso@hotmail.com

*Corresponding author: limanetoagro@hotmail.com
} 
reducing lateral water loss, can be a viable alternative in bell pepper cultivation. When side coating of the planting pits in yellow passion fruit was used, Cavalcante et al. (2005) concluded that the side coating helped maintain a higher soil humidity, providing an increase in fruit production.

In addition to reducing the volume of water applied, the nutritional requirements of plants must be met in order to obtain economically viable yields. In this regard, vegetable producers apply organic inputs, such as biofertilizers, which provide nutrients to the plants, to maintain a more balanced plant nutritional status (Borges et al., 2016; Oliveira et al., 2014; Sediyama et al., 2014). As such, the objective of this study was to evaluate the effects of side coating with polyethylene film, mulching with sisal residue and application of chemically enriched bovine biofertilizer on the fruit production and chlorophyll content in bell pepper plants.

\section{MATERIALS AND METHODS}

\section{Site description}

This work was conducted in the municipal district of Nova Floresta, a semi-arid area in the State of Paraíba, Brazil, 6 $6^{\circ} 26^{\prime} 40^{\prime \prime}$ south latitude and $36^{\circ} 12^{\prime} 04^{\prime \prime}$ west longitude, at an altitude of $669 \mathrm{~m}$ above sea level, between the months of August and February 2010/2011. Based on the Köppen classification system (Alvares et al., 2013), the climate of the region is hot and dry, with rainfall concentrated in the period from March to July.

The annual cumulative precipitation in 2010 and 2011 was 449.9 and $1036.7 \mathrm{~mm}$, respectively. The total rainfall recorded during the trial period was $312.8 \mathrm{~mm}$ (AESA, 2020). The minimum, average and maximum temperatures in the years 2010 and 2011 were 19.6 and 19.0; 25.5 and 25.4; 32.5 and $31.8^{\circ} \mathrm{C}$, respectively (Table 1 ).

The soil of the experimental area, according to the criteria of the Brazilian System of Soil Classification (SiBCS) (EMBRAPA, 2013), was classified as a Eutrophic Yellow Latosol. Before the establishment of the experiment, soil samples at depths of 0-15 and $15-30 \mathrm{~cm}$ and samples of the manure used in the pits were collected to determine their chemical attributes (Table 2), using the methodologies suggested by Donagema et al. (2011). The soil was evaluated as well as the salinity of the saturation extract (Richards, 1954) and the physical attributes (Donagema et al., 2011), which are presented in Table 3.

\section{Biofertilizer production}

The chemically enriched biofertilizer was obtained by anaerobic fermentation of a mixture of equal volumes of fresh manure and water (not saline or chlorinated), $1 \%$ MB-4 rock powder (17.82\% of $\left.\mathrm{Mg}^{2+}\right), 1 \%$ ash (13.61 $\mathrm{cmol}_{\mathrm{c}}$ $\mathrm{dm}^{-3}$ of $\left.\mathrm{K}^{+}\right), 1 \%$ brown sugar and $1 \%$ milk in a polyethylene biodigester with a capacity of $240 \mathrm{~L}$. This container was kept in the shade and hermetically sealed for 30 days. During this preparation period, homogenization by agitation occurred every $24 \mathrm{~h}$ for better efficiency of fermentation (Cavalcante et al., 2019). To release the gas produced by fermentation, a hose was connected to the top of the container that, along with the other extremities, was kept submerged in a container with water to prevent air from entering.

After fermentation but prior to application to the soil, three samples of the biofertilizer were collected at the top, middle and bottom of the biodigester and diluted in water at a proportion of 1:1 for evaluation of the electrical conductivity, $\mathrm{pH}$ and chemical composition of the water used for irrigation (Richards, 1954), as indicated in Table 4.

\section{Experimental design and field management}

The experimental design was a randomized block design with four repetitions that adopted a $2 \times 2 \times 2$ factorial scheme totaling 32 plots, each consisting of 21 plants, for a total of 672 pepper (Capsicum anпиит cultivar Interprise) plants. The factorial corresponded to soil with and without chemically enriched bovine biofertilizer; soil with and without mulch, to reduce water

Table 1: Monthly mean values of temperature and precipitation observed in during the research period

\begin{tabular}{|c|c|c|c|c|}
\hline \multirow{2}{*}{ Month } & \multicolumn{3}{|c|}{${ }^{1}$ Temperature $\left({ }^{\circ} \mathbf{C}\right)$} & \multirow{2}{*}{$\frac{{ }^{2} \text { Precipitation }}{(\mathrm{mm})}$} \\
\hline & Minimum & Mean & Maximum & \\
\hline August/2010 & 17 & 22.94 & 29 & 6.6 \\
\hline September/2010 & 18 & 24.07 & 32 & 9.4 \\
\hline October/2010 & 19 & 26.15 & 34 & 10.0 \\
\hline November/2010 & 20 & 26.55 & 33 & 0.0 \\
\hline December/2010 & 20 & 26.26 & 33 & 27.2 \\
\hline January/2011 & 20 & 25.69 & 32 & 201.6 \\
\hline February/2011 & 21 & 26.04 & 32 & 58.0 \\
\hline Mean/Sum & 19.3 & 25.4 & 32.1 & 312.8 \\
\hline
\end{tabular}

Source: ${ }^{1}$ AGRITEMPO (2020) - Weather station: TRMM. 7499 - Cuité, PB. Latitude: -6.5; Longitude: -36. ${ }^{2}$ AESA (2020). 
loss by evaporation with sisal residues $5 \mathrm{~cm}$ in thickness; and soil with and without side coating of the grooves with plastic polyethylene film, to reduce water loss by lateral movement of water.

The grooves were built with a length of $10 \mathrm{~m}$ and a width and depth of $40 \mathrm{~cm}$. The grooves were separated by $1 \mathrm{~m}$ and coated with a $150-\mu \mathrm{m}$ plastic film, as suggested by Cavalcante et al. (2005) to reduce water losses in yellow passion fruit. The grooves were then filled with the soil mix from the top layer. Afterward, the pits were opened in the grooves with dimensions of $30 \times 30 \times 30 \mathrm{~cm}$, and $3.5 \mathrm{~kg}$ of cow manure was added, with $4 \%$ moisture, to raise the soil organic matter content to $4 \%$.

The seedlings were prepared at the start of the second week in August 2010 in polyethylene trays of 200 cells using Plantmax ${ }^{\circledR}$ substrate and transplanted 28 days after sowing (DAS). The plants were spaced $1 \mathrm{~m}$ between rows and $0.5 \mathrm{~m}$ between plants, corresponding to 21 plants per plot, and the 10 middle plants of each plot were evaluated.

The chemically enriched biofertilizer, after being diluted in water $(1: 1)$, was applied manually to the soil at a rate of $10 \mathrm{~L} \mathrm{~m}^{-2}$ (Santos, 1992) one week before transplanting and at a rate of $1 \mathrm{~L} \mathrm{plant}^{-1}$, applied to the canopy area of the tops of the plants, at 60 days after transplanting (DAT), a time that coincided with the beginning of the flowering period and increased nutritional requirements of the plants (Marcussi et al., 2004). The treatments without biofertilizer received the same volume of water as the organic liquid inputs.

Table 2: Results of the chemical analyses as well as the soil fertility and cow manure used

\begin{tabular}{|c|c|c|c|c|}
\hline \multirow{2}{*}{ Chemical attributes } & \multicolumn{2}{|c|}{ Depths (cm) } & \multirow{2}{*}{\multicolumn{2}{|c|}{ Cow manure }} \\
\hline & $0-15$ & $15-30$ & & \\
\hline $\mathrm{pH}$ in water $(1: 2.5)$ & 6.44 & 6.49 & $\mathrm{pH}$ in water $(1: 2.5)$ & 8.48 \\
\hline $\mathrm{OM}\left(\mathrm{g} \mathrm{kg}^{-1}\right)$ & 10.27 & 6.81 & $\mathrm{OM}\left(\mathrm{g} \mathrm{kg}^{-1}\right)$ & 412.73 \\
\hline $\mathrm{P}\left(\mathrm{mg} \mathrm{dm}^{-3}\right)$ & 25.48 & 9.56 & $\mathrm{P}\left(\mathrm{mg} \mathrm{dm}^{-3}\right)$ & 668.44 \\
\hline $\mathrm{K}^{+}\left(\mathrm{mg} \mathrm{dm}^{-3}\right)$ & 116.00 & 76.14 & $\mathrm{~K}^{+}\left(\mathrm{mg} \mathrm{dm}^{-3}\right)$ & 2361.20 \\
\hline $\mathrm{Ca}^{2+}\left(\mathrm{cmol}_{\mathrm{c}} \mathrm{dm}^{-3}\right)$ & 3.25 & 2.85 & $\mathrm{Ca}^{2+}\left(\mathrm{cmol}_{\mathrm{c}} \mathrm{dm}^{-3}\right)$ & 4.55 \\
\hline $\mathrm{Mg}^{2+}\left(\mathrm{cmol}_{\mathrm{c}} \mathrm{dm}^{-3}\right)$ & 1.00 & 0.85 & $\mathrm{Mg}^{2+}\left(\mathrm{cmol}_{\mathrm{c}} \mathrm{dm}^{-3}\right)$ & 6.20 \\
\hline $\mathrm{Na}^{+}\left(\mathrm{cmol}_{\mathrm{c}} \mathrm{dm}^{-3}\right)$ & 0.40 & 0.16 & $\mathrm{Na}^{+}\left(\mathrm{cmol}_{c} \mathrm{dm}^{-3}\right)$ & 5.58 \\
\hline $\mathrm{SB}\left(\mathrm{cmol}_{\mathrm{c}} \mathrm{dm}^{-3}\right)$ & 4.95 & 4.05 & $\mathrm{SB}\left(\mathrm{cmol}_{\mathrm{c}} \mathrm{dm}^{-3}\right)$ & 22.37 \\
\hline $\mathrm{H}^{+}+\mathrm{Al}^{3+}\left(\mathrm{cmol}_{\mathrm{c}} \mathrm{dm}^{-3}\right)$ & 1.40 & 1.73 & $\mathrm{H}^{+}+\mathrm{Al}^{3+}\left(\mathrm{cmol}_{\mathrm{c}} \mathrm{dm}^{-3}\right)$ & 2.31 \\
\hline $\mathrm{Al}^{3+}\left(\mathrm{cmol}_{\mathrm{c}} \mathrm{dm}^{-3}\right)$ & 0.00 & 0.00 & $\mathrm{Al}^{3+}\left(\mathrm{cmol}_{\mathrm{c}} \mathrm{dm}^{-3}\right)$ & - \\
\hline $\operatorname{CEC}\left(\mathrm{cmol}_{\mathrm{c}} \mathrm{dm}^{-3}\right)$ & 6.35 & 5.78 & $\mathrm{CEC}\left(\mathrm{cmol}_{\mathrm{c}} \mathrm{dm}^{-3}\right)$ & - \\
\hline $\mathrm{V}(\%)$ & 77.95 & 70.12 & $\mathrm{~V}(\%)$ & - \\
\hline
\end{tabular}

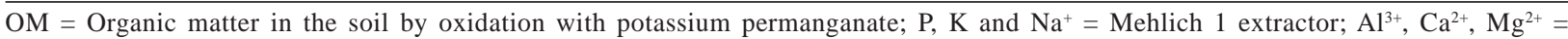

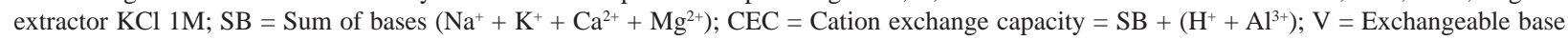
saturation $(100 * \mathrm{SB} / \mathrm{CEC})$.

Table 3: Chemical attributes as well as the salinity and soil physical properties of the experimental area

\begin{tabular}{|c|c|c|c|c|c|}
\hline Salinity of soil & $0-15 \mathrm{~cm}$ & $15-30 \mathrm{~cm}$ & Physical attributes & $0-15$ & $15-30$ \\
\hline EC at $25^{\circ} \mathrm{C}\left(\mathrm{dS} \mathrm{m} \mathrm{m}^{-1}\right)$ & 1.40 & 1.70 & Soil bulk density $\left(\mathrm{g} \mathrm{cm}^{-3}\right)$ & 1.64 & 1.66 \\
\hline $\mathrm{pH}$ & 7.28 & 6.86 & Soil particle density $\left(\mathrm{g} \mathrm{cm}^{-3}\right)$ & 2.68 & 2.68 \\
\hline $\mathrm{Ca}^{2+}\left(\mathrm{mmol} \mathrm{L}_{\mathrm{c}}^{-1}\right)$ & 3.20 & 5.80 & Total porosity $\left(\mathrm{m}^{3} \mathrm{~m}^{-3}\right)$ & 0.39 & 0.38 \\
\hline $\mathrm{Mg}^{2+}\left(\mathrm{mmol}_{\mathrm{c}} \mathrm{L}^{-1}\right)$ & 2.60 & 4.70 & Sand $\left(\mathrm{g} \mathrm{kg}^{-1}\right)$ & 580 & 617 \\
\hline $\mathrm{Na}^{+}\left(\operatorname{mmol}_{\mathrm{c}} \mathrm{L}^{-1}\right)$ & 1.22 & 0.98 & Silt $\left(\mathrm{g} \mathrm{kg}^{-1}\right)$ & 135 & 192 \\
\hline $\mathrm{K}^{+}\left(\mathrm{mmol}_{\mathrm{c}} \mathrm{L}^{-1}\right)$ & 0.91 & 0.76 & Clay $\left(\mathrm{g} \mathrm{kg}^{-1}\right)$ & 285 & 191 \\
\hline $\mathrm{Cl}^{-}\left(\mathrm{mmol}_{\mathrm{c}} \mathrm{L}^{-1}\right)$ & 12.50 & 5.00 & Clay disper. in water $\left(\mathrm{g} \mathrm{kg}^{-1}\right)$ & 79 & 26 \\
\hline $\mathrm{CO}_{3}{ }^{2-}\left(\mathrm{mmol}_{\mathrm{c}} \mathrm{L}^{-1}\right)$ & 0.00 & 0.00 & Index of flocculation $(\%)$ & 72.3 & 86.4 \\
\hline $\mathrm{HCO}_{3}^{-}\left(\mathrm{mmol}_{\mathrm{c}} \mathrm{L}^{-1}\right)$ & 2.00 & 0.50 & Index of dispersion $(\%)$ & 27.7 & 13.6 \\
\hline $\mathrm{SO}_{4}^{2-}\left(\mathrm{mmol}_{\mathrm{c}} \mathrm{L}^{-1}\right)$ & 0.92 & 0.79 & Water content ${ }_{\mathrm{FC}}\left(\mathrm{g} \mathrm{kg}^{-1}\right)$ & 8.32 & 9.57 \\
\hline $\operatorname{SAR}\left(\mathrm{mmol} \mathrm{L}^{-1}\right)^{1 / 2}$ & 0.72 & 0.43 & Water content ${ }_{\mathrm{PMP}}\left(\mathrm{g} \mathrm{kg}^{-1}\right)$ & 3.32 & 3.87 \\
\hline $\operatorname{ESP}(\%)$ & - & - & Water available $\left(\mathrm{g} \mathrm{kg}^{-1}\right)$ & 5.00 & 5.60 \\
\hline Classification & NS & NS & Classification & SCL & SCL \\
\hline
\end{tabular}

EC = electrical conductivity; SAR = Sodium adsorption ratio $=\mathrm{Na}^{+} /\left[\left(\mathrm{Ca}^{2+}+\mathrm{Mg}^{2+}\right) / 2\right]^{0,5} ; \mathrm{ESP}=$ Exchangeable sodium percentage; $\mathrm{NS}=$ not saline; Index of flocculation $=$ [(Clay - Clay dispersed in water $) /$ Clay $] 100$; Index of dispersion $=(100-$ Index of flocculation $)$; Water content $_{\mathrm{FC}}=$ Water content at field capacity, tension of $-0.010 \mathrm{MPa}$; Water content ${ }_{\mathrm{PWP}}=$ Water content at the permanent wilting point, tension of $-1.5 \mathrm{MPa}$, SCL $=$ Sandy clay loam; $=100\left(\mathrm{Na}^{+} / \mathrm{CEC}\right)$. 
Irrigation was provided daily by the drip-irrigation method using drip tape with drippers spaced $20 \mathrm{~cm}$ apart at a flow rate of $4.75 \mathrm{~L} \mathrm{~h}^{-1}$, which was based on the evaporation of water in a class " $A$ " tank installed at the location of the experiment. The irrigation depth applied in all treatments was estimated based on the crop evapotranspiration $(\mathrm{ETc})$, using the equation: $\mathrm{ETc}=\mathrm{ET}_{\mathrm{o}}$ $\times \mathrm{Kc}$, which $\mathrm{ET}_{\mathrm{o}}$ corresponds to reference evapotranspiration and $\mathrm{Kc}$ to crop coefficient. The Kc values used for the culture were 0.40 at seedling setting stage; 0.40 at vegetative stage; 0.70 at flowering/ fructification stage; 1.05 at full flowering stage; 0.85 at in the declining production stage (Marouelli \& Silva, 2012).

\section{Sampling and measurements}

At 70 DAT, whole leaves were collected (the first fully developed leaf from the top) to determine the concentration of the photosynthetic pigments chlorophyll $a$ and $b$ as well as the total chlorophyll, as suggested by Malavolta et al. (1997) for the assessment of the nutritional status of plants. The leaves, after being collected, were immediately placed in aluminum envelopes, packed into a thermal box with ice and taken to the lab.

In the laboratory, plant tissue samples were removed from the middle third of each leaf, and the fresh mass was obtained using a precision analytical balance. The material was then macerated and packaged into containers coated with aluminum sheets. Twenty-five milliliters of $80 \%$ acetone was added, and the materials were kept cold (8 ${ }^{\circ} \mathrm{C}$ ) for $24 \mathrm{~h}$, after which they were filtered on filter paper for 5 min (Arnon, 1949).

Table 4: Chemical composition of the biofertilizer and the irrigation water as well as the salinity

\begin{tabular}{lcc}
\hline Variables & $\begin{array}{c}\text { Enriched } \\
\text { biofertilizer }\end{array}$ & Water \\
\hline $\mathrm{pH}$ & 6.21 & 3.39 \\
$\mathrm{EC}$ at $25 \mathrm{e}^{\left.,{ }^{\circ} \mathrm{C}(\mathrm{dS} \mathrm{m})^{-1}\right)}$ & 11.49 & 1.50 \\
$\mathrm{Ca}^{2+}\left(\mathrm{mmol}_{\mathrm{c}} \mathrm{L}^{-1}\right)$ & 34.25 & 0.86 \\
$\mathrm{Mg}^{2+}\left(\mathrm{mmol}_{\mathrm{c}} \mathrm{L}^{-1}\right)$ & 29.25 & 1.99 \\
$\mathrm{Na}^{+}\left(\mathrm{mmol}_{\mathrm{c}} \mathrm{L}^{-1}\right)$ & 14.87 & 11.84 \\
$\mathrm{~K}^{+}\left(\mathrm{mmol}_{\mathrm{c}} \mathrm{L}^{-1}\right)$ & 36.74 & 0.52 \\
$\mathrm{Cl}^{-}\left(\mathrm{mmol}_{\mathrm{c}} \mathrm{L}^{-1}\right)$ & 52.50 & 14.20 \\
$\mathrm{CO}_{3}{ }^{2-}\left(\mathrm{mmol}_{\mathrm{c}} \mathrm{L}^{-1}\right)$ & 3.84 & $\mathrm{Absence}$ \\
$\mathrm{HCO}_{3}^{-}\left(\mathrm{mmol}_{\mathrm{c}} \mathrm{L}^{-1}\right)$ & 12.49 & 0.00 \\
$\mathrm{SO}_{4}^{2-}\left(\mathrm{mmol}_{\mathrm{c}} \mathrm{L}^{-1}\right)$ & 45.86 & 0.92 \\
$\mathrm{SAR}^{2}\left(\mathrm{mmol} \mathrm{L}^{-1}\right)^{1 / 2}$ & 2.64 & 9.87 \\
\hline $\mathrm{Classification}^{* *}$ & $\mathrm{C}_{4} \mathrm{~S}_{1}$ & $\mathrm{C}_{2} \mathrm{~S}_{2}$ \\
\hline
\end{tabular}

$\mathrm{EC}=$ electrical conductivity; $\mathrm{SAR}=$ Sodium adsorption ratio $=\mathrm{Na}^{+}$ $\left[\left(\mathrm{Ca}^{+}+\mathrm{Mg}^{+}\right) / 2\right]^{0,5} ; * *=$ Classification according to Ayers \& Westcot (1999); $\mathrm{C}_{2}$ and $\mathrm{C}_{4}=$ Respectively medium and very high risk of salinization soil; $\mathrm{S}_{1}$ and $\mathrm{S}_{2}=$ Respectively low and medium risk of sodification soil.
The absorbances of the extracts were obtained using an absorption spectrophotometer at wavelengths of 646.8 $\left(\mathrm{A}_{646.8}\right)$ and $663.2 \mathrm{~nm}\left(\mathrm{~A}_{663.2}\right)$, with $80 \%$ acetone used as a blank. To calculate the concentrations of chlorophyll $a$ and $b$ and the total chlorophyll (Chl $a$, Chl $b$ and $\mathrm{Chl} t$, respectively), the equations described by Lichtenthaler (1987) were used.

$$
\begin{aligned}
& \text { Chlorophyll } a(\mathrm{Chl} a)=\left(12.25 \mathrm{~A}_{663.2}\right)-\left(2.79 \mathrm{~A}_{646.8}\right) \\
& \text { Chlorophyll } b(\mathrm{Chl} b)=\left(21.50 \mathrm{~A}_{646.8}\right)-\left(5.10 \mathrm{~A}_{663.2}\right) \\
& \text { Total chlorophyll }(\mathrm{Chl} t)=\left(7.15 \mathrm{~A}_{663.2}\right)-\left(18.71 \mathrm{~A}_{646.8}\right)
\end{aligned}
$$

The values of the Chl $a, \mathrm{Chl} b$ and $\mathrm{Chl} t$ levels in the leaves were transformed and expressed in milligrams per gram of fresh matter ( $\left.\mathrm{mg} \mathrm{g}^{-1} \mathrm{FM}\right)$.

Harvest of the fruits occurred twice weekly throughout the production cycle for calculation of the number of fruits per plant and the plant production and productivity.

\section{Statistical analysis}

The data were subjected to analysis of variance, and the averages between interactions were compared by the Tukey test at the 5\% level of probability using the Sisvar software program (Ferreira, 2011). The averages concerning the factors isolated by the $\mathrm{F}$ test are conclusive between two values (Pimentel-Gomes, 2009).

\section{RESULTS AND DISCUSSION}

During the bell pepper growing period, the minimum, average and maximum air temperatures were 19.3, 25.4 and $32.1^{\circ} \mathrm{C}$, respectively (Table 1). According to Mercado et al. (1997), the optimal temperature for pepper growth is 25 and $30{ }^{\circ} \mathrm{C}$. When plants are subjected to temperatures below $15^{\circ} \mathrm{C}$ or above $32{ }^{\circ} \mathrm{C}$, growth is usually slowed and yield decreases.

\section{Fruit production}

The chemically enriched biofertilizer and mulch with sisal residue did not exert direct effects on the productivity or on the components of production, expressed by the number of fruits and the production per plant. On the other hand, the side coating of grooves with polyethylene film for protection against lateral water movement losses resulted in an increase from 13.6 to 17.3 of the average number of fruits per plant, which represents an increase of $27.4 \%$ (Figure 1). These values are close to the range of 15.6 to 18.6 fruits per plant reported by Cosic et al. (2015) in bell pepper plants under irrigated conditions. These results are also in agreement with those of Cavalcante $e t$ al. (2005), who established that the use of this technique increases yellow passion fruit production up to $62 \%$.

The use of the lining in the groves of the plantings, which reduces the loss of water due to lateral movement, 
must have contribution to maintaining of soil moisture throughout the day. This would enable greater absorption of water and nutrients by the plants, resulting in increased production, as recorded by Braga et al. (2017) and Rocha et al. (2018) in the cultivation of melon and in bell pepper, respectively.

The superiority of the treatments with side coating of grooves, noted for their number of fruits per plant, was also observed in the individual plant production (Figure 2). According to the results, when the penetration of water on the sides of the grooves of the plantings was contained by the action of the plastic film, there was a $22.7 \%$ increase in the production of fruit per plant. The increased availability of water to the plants and better adjustment of the temperature of the soil were possibly caused by the use of the side coating of the grooves, resulting in increases in stomatal conductance, transpiration and in intercellular $\mathrm{CO}_{2}$ concentrations, contributing to an increased rate of net photosynthesis of the plants, reflected positively by the production potential (Liang et al., 2011; Malika et al., 2019; Sezen et al., 2019).
The increase in the number of fruits and plant production provided by the use of the side coating of the ridges was reflected in the increase in productivity (Figure 3 ). The reduction of water loss by the use of the polyethylene film increased the productivity from 19.42 to $23.78 \mathrm{t} \mathrm{ha}^{-1}$, providing a $22.45 \%$ gain. Such results, evidenced also by Cavalcante et al. (2005) in yellow passion fruit genotypes, indicate that the lining of the grooves of the plantings with polyethylene film improves the water use efficiency of the crops; therefore, this technique is recommended for use in horticulture, especially in semi-arid regions.

The enhanced productivity provided by the use of the side coating of the ridges with plastic film seems promising. The productivity values obtained in this work (Figure 3) are located in the ranged of 13.46 to $21.33 \mathrm{tha}^{-1}$, obtained by Ashrafuzzaman et al. (2011) in assessing the use of different plastic mulches on the production of bell peppers. Despite a significant increase, the results are still well below the range of 30.9 to $34.0 \mathrm{t} \mathrm{ha}^{-1}$ found by Kuşçu et al. (2016) in red peppers under fertigation with nitrogen.

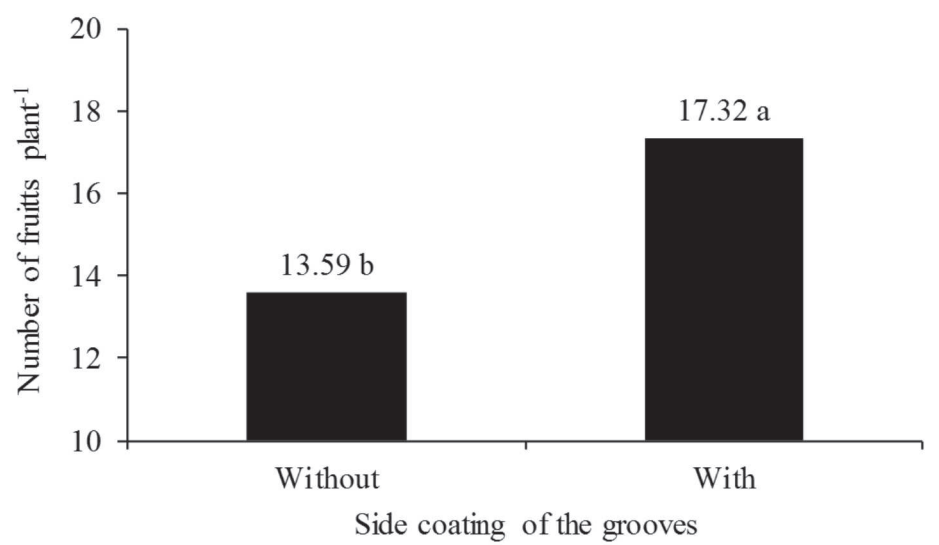

Figure 1: Average values of the number of fruits per plant of bell pepper grown in soil without and with side coating of the grooves.

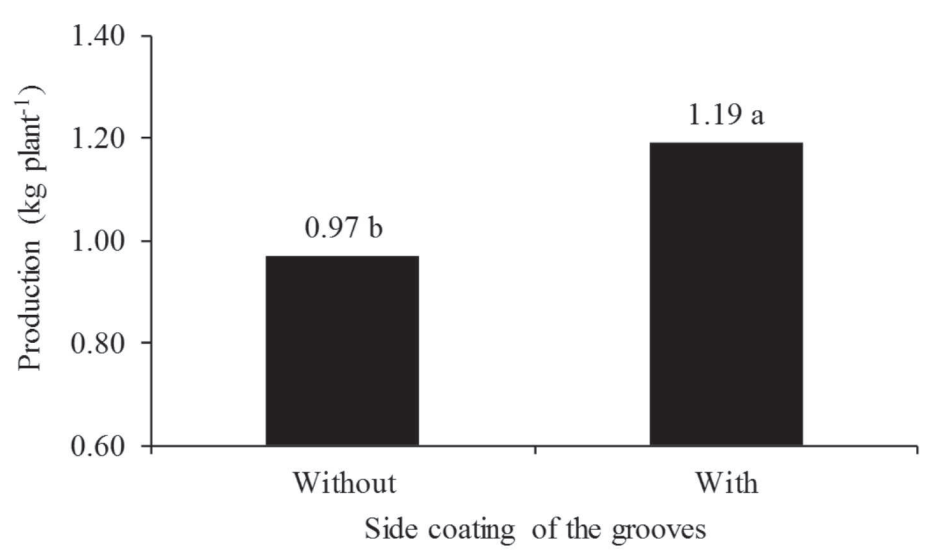

Figure 2: Production of bell pepper per plant grown in soil without and with side coating of the grooves. 
The use of plastic soil cover of various colors and organic materials reduces the loss of water by evaporation, increases the availability of nutrients and reduces the variability of soil moisture during the cultivation cycle, enabling greater growth of the roots, which results in increased fruit production (Kader et al., 2017).

\section{Leaf chlorophyll content}

Foliar levels of Chl $a$ in the bell pepper plants were influenced by the side coating of the grooves, mulching of soil and application of the chemically enriched biofertilizer (Table 5). When the side coating of grooves was used by itself (i.e., in the absence of enriched biofertilizer and soil mulch), the levels of Chl $a$ did not vary. However, in the soil without biofertilizer and with mulch, the levels of Chl $a$ increased from 0.57 to $0.70 \mathrm{mg} \mathrm{g}^{-1} \mathrm{FM}$ with use of side coating, a gain of $22.8 \%$. This trend was also observed by Ashrafuzzaman et al. (2011), who used different types of plastics as soil cover in the same culture, which resulted in higher levels of Chl $a$.

According to Malika et al. (2019), an adequate supply of water to plants induces an increase in the levels of chlorophyll, reinforcing the effects of the side coating of the grooves and of the mulch to keep soil wetter and cooler. A study by Amer et al. (2009) showed that cucumber (Cucumis sativus L.) plants under irrigated conditions exhibit positive correlations between soil moisture content and Chl $a$ and Chl $b$, with an effective increase in productivity.

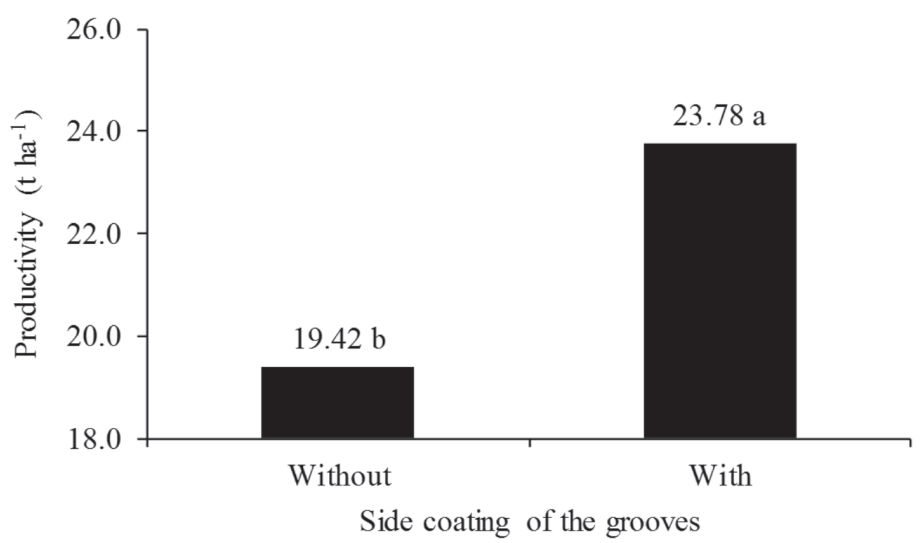

Figure 3: Productivity of bell pepper grown in soil without and with side coating of the grooves.

Table 5: Levels of chlorophyll $a$ in leaves of bell pepper plants grown in soil without and with side coating of grooves, mulch and biofertilizer

\begin{tabular}{|c|c|c|c|c|}
\hline \multirow{3}{*}{$\begin{array}{l}\text { Side coating } \\
\text { of the grooves }\end{array}$} & \multicolumn{2}{|c|}{ Soil without biofertilizer } & \multicolumn{2}{|c|}{ Soil with biofertilizer } \\
\hline & Without mulch & With mulch & Without mulch & With mulch \\
\hline & \multicolumn{4}{|c|}{ Chlorophyll $a\left(\mathrm{mg} \mathrm{g}^{-1} \mathrm{FM}\right)$} \\
\hline Without & 0.65 Aa $\alpha$ & $0.57 \mathrm{Ab} \alpha$ & $0.55 \mathrm{Ba} \alpha$ & $0.67 \mathrm{Aa} \alpha$ \\
\hline With & $0.68 \mathrm{Aa} \alpha$ & $0.70 \mathrm{Aa} \alpha$ & $0.62 \mathrm{Aa} \alpha$ & $0.54 \mathrm{Ab} \beta$ \\
\hline
\end{tabular}

Means followed by the same uppercase letter in the rows and lowercase in the columns do not differ from each other by the Tukey test at $5 \%$ probability. Equal greek letters in the line do not differ from each other by the Tukey test at $5 \%$ probability. DMS $=0.11 ; \mathrm{CV}=12.94 \%$.

Rev. Ceres, Viçosa, v. 68, n.1, p. 039-046, jan/feb, 2021 
Table 6: Levels of chlorophyll $b$ in leaves of bell pepper plants grown in soil without and with side coating of grooves, mulch and enriched biofertilizer

\begin{tabular}{|c|c|c|c|c|}
\hline \multirow{3}{*}{$\begin{array}{l}\text { Side coating } \\
\text { of the grooves }\end{array}$} & \multicolumn{2}{|c|}{ Soil without biofertilizer } & \multicolumn{2}{|c|}{ Soil with biofertilizer } \\
\hline & Without mulch & With mulch & Without mulch & With mulch \\
\hline & \multicolumn{4}{|c|}{ Chlorophyll $b\left(\mathrm{mg} \mathrm{g}^{-1} \mathbf{F M}\right)$} \\
\hline Without & $0.27 \mathrm{Aa} \alpha$ & $0.24 \mathrm{Ab} \alpha$ & $0.22 \mathrm{Ba} \beta$ & $0.28 \mathrm{Aa} \alpha$ \\
\hline With & $0.28 \mathrm{Aa} \alpha$ & $0.29 \mathrm{Aa} \alpha$ & $0.26 \mathrm{Aa} \alpha$ & $0.24 \mathrm{Aa} \beta$ \\
\hline
\end{tabular}

Means followed by the same uppercase letter in the rows and lowercase in the columns do not differ from each other by the Tukey test at $5 \%$ probability. Equal greek letters in the line do not differ from each other by the Tukey test at $5 \%$ probability. DMS $=0.046 ; \mathrm{CV}=$ $12.50 \%$.

Table 7: Total chlorophyll content in leaves of bell pepper plants grown in soil without and with side coating of grooves, mulch and enriched biofertilizer

\begin{tabular}{|c|c|c|c|c|}
\hline \multirow{3}{*}{$\begin{array}{l}\text { Side coating } \\
\text { of the grooves }\end{array}$} & \multicolumn{2}{|c|}{ Soil without biofertilizer } & \multicolumn{2}{|c|}{ Soil with biofertilizer } \\
\hline & Without mulch & With mulch & Without mulch & With mulch \\
\hline & \multicolumn{4}{|c|}{ Total chlorophyll (mg g ${ }^{-1}$ FM) } \\
\hline Without & $0.92 \mathrm{Aa} \alpha$ & $0.81 \mathrm{Ab} \alpha$ & $0.77 \mathrm{Ba} \alpha$ & $0.95 \mathrm{Aa} \alpha$ \\
\hline With & $0.96 \mathrm{Aa} \alpha$ & $1.00 \mathrm{Aa} \alpha$ & $0.88 \mathrm{Aa} \alpha$ & $0.79 \mathrm{Ab} \beta$ \\
\hline
\end{tabular}

Means followed by the same uppercase letter in the rows and lowercase in the columns do not differ from each other by the Tukey test at $5 \%$ probability. Equal greek letters in the line do not differ from each other by the Tukey test at $5 \%$ probability. DMS $=0.156$; CV $=$ $12.56 \%$.

a reduction in the level of $\mathrm{Chl} t$ from 1.0 to $0.79 \mathrm{mg} \mathrm{g}^{-1} \mathrm{FM}$. This decrease may be due to the high electrical conductivity of the enriched biofertilizer (Table 4), which provides high levels of $\mathrm{Ca}^{2+}, \mathrm{Mg}^{2+}, \mathrm{Na}^{+}$and $\mathrm{Cl}^{-}($Cavalcante et al., 2019; Oliveira et al., 2014; Sediyama et al., 2014), and the largest buildup of moisture, provided by the use of all of these techniques together, could have caused a nutritional imbalance, resulting in the absorption of some nutrients in excess, such as $\mathrm{Na}^{+}$and $\mathrm{Cl}^{-}$, which are toxic to plants (Lima et al., 2018). A similar situation was recorded by Corrêa et al. (2009), who concluded that high input rates of cow and poultry manure inhibit the production of chlorophyll despite raising the levels of chlorophyll in plants. For these authors, the decreases were attributed to excess nutrients provided by the inputs in the soil solution. The high electrical conductivity of the biofertilizer $\left(11.49 \mathrm{dS} \mathrm{m}^{-1}\right)$ may have increased the concentration of salts above the tolerable limit by the plants, causing decreases in chlorophyll concentration due to increased chlorophyllase enzyme activity, which degrades chlorophyll (Santos, 2004).

In semi-arid regions, where water availability is not always sufficient to meet crop requirements, the use of technologies that allow efficient use of water is essential to maintain agricultural activity. Even with the scarcity of water resources, the lateral coating of the planting furrows with polyethylene film, combined with the use of mulch made it possible to obtain high yields of pepper. These cultivation practices are promising and can be used by pepper producers in the region.

\section{CONCLUSIONS}

The side coating of the grooves with polyethylene plastic film increased the production of fruit in individual plants, promoting the productivity of bell pepper cultivation.

The side coating of grooves associated with mulching in the soil without biofertilizer, increased the levels of chlorophyll $a$, chlorophyll $b$ and total chlorophyll.

When used in association with side coating and mulch, the enriched biofertilizer reduced the levels of chlorophyll in the plants.

\section{ACKNOWLEDGEMENTS, FINANCIAL SUPPORT AND FULL DISCLOSURE}

This work was supported by National Institute of Science and Technology in Salinity (INCTSal) and the National Council for Scientific and Technological Development (CNPq) for the financial support.

The authors declare no conflict of interest for the submitted manuscript/publication.

\section{REFERENCES}

AESA - Agência Executiva de Gestão das Águas do Estado da Paraíba (2020) Meteorologia. Available at: http:// www.aesa.pb.gov.br. Accessed on: July 1'st, 2020.

AGRITEMPO - Sistema de Monitoramento Agrometeorológico (2020) Available at: https://www.agritempo.gov.br/agritempo/ jsp/Estatisticas/index.jsp?siglaUF $=P B$. Accessed on: July $10^{\text {th }}$, 2020.

Rev. Ceres, Viçosa, v. 68, n.1, p. 039-046, jan/feb, 2021 
Alvares CA, Stape JL, Sentelhas PC, Gonçalves JLM \& Sparovek G (2013) Köppen's climate classification map for Brazil. Meteorologische Zeitschrift, 22:711-728.

Amer KH, Midan SA \& Hatfield JL (2009) Effect of deficit irrigation and fertilization on cucumber. Agronomy Journal, 101:1556-1564.

Arnon DI (1949) Copper enzymes in isolated chloroplasts: polyphenoloxidases in Beta vulgaris. Plant Physiology, 24:115.

Ashrafuzzaman M, Halim MA, Ismail MR, Shahidullah SM \& Hossain A (2011) Effect of plastic mulch on growth and yield of chilli (Capsicum annuum L.). Brazilian Archives of Biology and Technology, 54:321-330.

Ayers RS \& Westcot DW (1999) A qualidade da água na agricultura. $2^{\text {nd }}$ ed. Campina Grande, UFPB. 153p.

Borges FRM, Viana Thales VA, Marinho AB, Pinheiro Neto LG \& Azevedo BM (2016) Gas exchange and leaf contents in bell pepper under energized water and biofertilizer doses. Revista Brasileira de Engenharia Agrícola e Ambiental, 20:533-538.

Braga MB, Marouelli WA, Resende GM, Moura MSB, Costa ND, Calgaro M \& Correia JS (2017) Coberturas do solo e uso de manta agrotêxtil (TNT) no cultivo do meloeiro. Horticultura Brasileira 35:147-153.

Cavalcante LF, Bezerra FTC, Souto AGL, Bezerra MAF, Lima GS, Gheyi HR, Ferreira JFS \& Beckmann-Cavalcante MZ (2019) Biofertilizers in horticultural crops. Comunicata Scientiae, 10:415-428.

Cavalcante LF, Costa JRM, Oliveira FKD, Cavalcante ÍHL \& Araújo FAR (2005) Produção do maracujazeiro-amarelo irrigado com água salina em covas protegidas contra perdas hídricas. Irriga, 10:229-240.

Corrêa RM, Pinto JEBP, Reis ES, Oliveira C, Castro EM \& Brant RS (2009) Características anatômicas foliares de plantas de orégano (Origanum vulgare L.) submetidas a diferentes fontes e níveis de adubação orgânica. Acta Scientiarum Agronomy, $31: 439-444$.

Cosic M, Djurovic N, Todorovic M, Maletic R, Zecevic B \& Stricevic R (2015) Effect of irrigation regime and application of kaolin on yield, quality and water use efficiency of sweet pepper. Agricultural Water Management, 148:139-147.

Donagema GK, Campos DVB, Calderano SB, Teixeira WG \& Viana JHM (2011) Manual de métodos de análise de solo. $2^{\text {nd }}$ ed. Rio de Janeiro, Centro Nacional de Pesquisa de Solo. 230p.

EMBRAPA - Empresa Brasileira de Pesquisa Agropecuária (2013) Sistema Brasileiro de Classificação de Solos. $3^{\text {rd }}$ ed. Brasília, Embrapa Solos. 353p.

Ferreira DF (2011) Sisvar: a computer statistical analysis system. Ciência e Agrotecnologia, 35:1039-1042.

Kader MA, Senge M, Mojid MA \& Ito K (2017) Recent advances in mulching materials and methods for modifying soil environment. Soil \& Tillage Research, 168:155-166.

Kuşçu H, Turhan A, Özmen N, Aydinol P \& Demir AO (2016) Response of red pepper to deficit irrigation and nitrogen fertigation. Archives of Agronomy and Soil Science, 62:13961410 .

Liang YL, Wu X, Zhu JJ, Zhou MJ \& Peng Q (2011) Response of hot pepper (Capsicum annuum L.) to mulching practices under planted greenhouse condition. Agricultural Water Management, 99:111-120.
Lichtenthaler HK (1987) Chlorophylls and carotenoids: pigment photosynthetic biomembranes. Methods in Enzymology, 148:362-385

Lima NS, Silva ÊFF, Menezes D, Camara TR \& Willadino LG (2018) Fruit yield and nutritional characteristics of sweet pepper grown under salt stress in hydroponic system. Revista Caatinga, 31:297-305

Malavolta E, Vitti GC \& Oliveira AS (1997) Avaliação do Estado Nutricional das Plantas: princípios e aplicações. Piracicaba, Associação Brasileira para Pesquisa da Potassa e do Fosfato. 319 p.

Malika LY, Deshabandu KSHT, Costa WAJM, Ekanayake S, Herath S \& Weerakoon WMW (2019) Physiological traits determining tolerance to intermittent drought in the Capsicum annuum complex. Scientia Horticulturae, 246:21-33.

Marcussi FFN, Villas Bôas RL, Godoy LJG \& Goto R (2004) Macronutrient accumulation and portioning in fertigated sweet pepper plants. Scientia Agrícola, 61:62-68.

Marouelli WA \& Silva WLC (2012) Irrigação na cultura do pimentão. Brasília, Embrapa/ Centro Nacional de Pesquisa de Hortaliças. 20p (Circular Técnica, 101).

Melo HFS, Souza ER, Duarte HHF, Cunha JC \& Santos HRB (2017) Gas exchange and photosynthetic pigments in bell pepper irrigated with saline water. Revista Brasileira de Engenharia Agrícola e Ambiental, 21:38-43.

Mercado JA, Reid MS, Valpuesta V, Quesada MA (1997) Metabolic changes and susceptibility to chilling stress in Capsicum anпиит plants grown at suboptimal temperature. Australian Journal of Plant Physiology, 24:759-767

Oliveira JR, Gomes RLF, Araújo ASF, Marini FS, Lopes JB \& Araújo RM (2014) Estado nutricional e produção da pimenteira com uso de biofertilizantes líquidos. Revista Brasileira de Engenharia Agrícola e Ambiental, 18:1241-1246.

Pimentel-Gomes F (2009) Curso de estatística experimental. 15 $5^{\text {nd }}$ ed. Piracicaba, Fealq. 451p.

Richards LA (1954) Diagnóstico y rehabilitación de suelos salinos y sódicos. Washington D., USDA. 172p.

Rocha PA, Santos MR, Donato SLR, Brito CFB \& Avila JS (2018) Bell pepper cultivation under different irrigation strategies in soil with and without mulching. Horticultura Brasileira 36:453460 .

Santos ACV (1992) Biofertilizantes líquidos: o defensivo agrícola da natureza. $2^{\text {nd }}$ ed. Niterói, EMATER. 162p.

Santos CV (2004) Regulation of chlorophyll biosynthesis and degradation by salt stress in sunflower leaves. Scientia Horticulturae, 103:93-99.

Santos HCA, Lima Junior JA, Silva ALP, Castro GLS \& Gomes RF (2020) Yield of fertigated bell pepper under different soil water tensions and nitrogen fertilization. Revista Caatinga, 33:172183.

Sediyama MAN, Santos MR, Vidigal SM, Pinto CLO \& Jacob LL (2014) Nutrição e produtividade de plantas de pimentão colorido, adubadas com biofertilizante de suíno. Revista Brasileira de Engenharia Agrícola e Ambiental, 18:588-594.

Sezen SM, Yazar A \& Tekin S (2019) Physiological response of red pepper to different irrigation regimes under drip irrigation in the Mediterranean region of Turkey. Scientia Horticulturae, 245:280-288 